Poetry

\title{
Nutritional health: pool and plunger
}

\section{Poetry}

To optimize lifestyle,

We must firmly restyle

Nature as a fit model,

We must do it old style

Eating, resting, exercise,

Are what we need harmonize

To get balance of three,

We must move and activize

For each meal and every day,

Needed working no delay

Running panting in sweat,

Is what not to keep away

No weekly or the longer,

Work out to cease the hunger

Do exercise every day,

Become pool and plunger. ${ }^{1-23}$

\section{Acknowledgements}

None.

\section{Conflict of interest}

Author declares that there is no conflict of interest.

\section{References}

1. Nikkhah A. A Realistic Weight Management Nutritional Regimen for Today's Life. J Nutr Health Food Eng. In Press. 2015.

2. Nikkhah A. Diabesity and Lifestyle. Curr Res Diabetes Obes J. 2015;1(1):CRDOJ.MS.ID.555552.

3. Nikkhah A. Gestational Fetal Genomics Bioengineering to Improve Individual and Public Health. Aus J Biotechnol Bioeng. 2015;2(4):1050.

4. Nikkhah A. A Time-Efficient Exercise Formula for Normalizing Obese Body Mass Index. Adv Obes Weight Manag Control. 2015;3(2) 00049.

5. Nikkhah A. Lifestyle Optimization: Today's Foremost Probiotic. $J$ Probiotics Health. 2015;3(2):e119.

6. Nikkhah A. Improving Life Quality via Circadian Timing of Nutrient Intake: Linking Ruminant Agriculture to Human Health. EC Agriculture. 2015;2(1):258-259.
Special Issue - 2015

Akbar Nikkhah

Department of Animal Sciences, University of Zanjan, Iran

Correspondence: Akbar Nikkhah, Chief Highly Distinguished Professor, Department of Animal Sciences, Faculty of Agricultural Sciences, University of Zanjan, Foremost Principal Highly Distinguished Elite-Generating Scientist, National Elite Foundation, Iran, Email anikkha@yahoo.com

Received: October I, 2015 | Published: October 5, 2015

7. Nikkhah A. Optimized Lifestyle via Timing of Food Intake: Bridging Ruminant Agriculture to Human Health. J Food Nutri. 2015;2(2):013.

8. Nikkhah A. Scheduling Exercise-Eating to Optimize Gut Probiotics: A Global Invention. J Probiotic Health. 2015;3:e118.

9. Nikkhah A. Establishing Regular Patterns of Cellular Mechanics to Minimize Oncogenesis: Animal Sciences Inspire. Aust J Vet Sci Anim Husb. 2015;2(2):1010.

10. Nikkhah A. Towards a Global Anti-Diabetes Exercise Program. J Bioprocess Biotechniq. 2015;5:e135.

11. Nikkhah A. Standardizing Appetite through Timing of Food Intake to Minimize Metabolic Disorders: A Veterinary Revelation. J Veterinar Sci Technol. 2015;6:e116.

12. Nikkhah A. Lifestyle Bioengineering via Scheduled Intake: Bridging Animal Agriculture to Human Medicine. Aust J Biotechnol Bioeng. 2015;2(3):1045.

13. Nikkhah A. Circadian Timing and Regularity of Physical Activity: A Novel Bioprocess to Prevent Devastating Modern Diseases. J Bioprocess Biotechniq. 2015;5:e131.

14. Nikkhah A. Nutrition is Ambition. J Nutr Health \& Food Engin in Press. 2015.

15. Nikkhah A. Science Edification Arts: The Ultimate Frontiers to Eradicate Economic Sanctions. The Open Access Journal of Resistive Economics. 2013;1(1):1-6.

16. Nikkhah A. Eating timing and diabetes. Int J Diabetol Vasc Dis Res. 2014;2(2):1.

17. Nikkhah A. Editorial: Science of the new times: A circle not a line. $A d v$ Crop Sci Technol. 2014;2:1.

18. Nikkhah A. When to Eat to Beat Obesity and Diabetes? Journal of Diabetes and Metabolism. 2014;5:7.

19. Nikkhah A. On Chronophysiomics: Prospects to Optimize Appetite and Health. SAJ Biotechnol. 2014;1:103.

20. Nikkhah A. Avoid Large Night Meals to Stay Fit. J Obes Weight Loss Ther. 2015;4:e115. 
21. Nikkhah A. Perspective: Nutrient Intake Chronophysiology: A Rising Public Health Concern. J Nutr Therap. 2014;3(4):156-157.

22. Nikkhah A. Intake Circadian Physiology: An Overlooked Public Health Concern. Endocrinol Metab Synd. 2015;1:1.
23. Nikkhah A. Discovering the Right Time to Take Food to Smash Diabetes. J Diabetes Res Ther. 2015;1:1 